\title{
Workshop - Feminist Engineering Education: Building a Community of Practice
}

\author{
Alice L. Pawley, Donna Riley, Susan M. Lord, and Trevor Harding \\ apawley@purdue.edu,driley@smith.edu, slord@sandiego.edu, tharding@calpoly.edu
}

\begin{abstract}
As a result of a series of papers and special sessions held at FIE between 2004 and 2008, a community of CSET educators interested in exploring feminist pedagogies has formed at FIE. Past participants in these sessions have expressed a desire to learn more about what makes a set of pedagogies "feminist." At the same time, there has been an increase in the number of research papers at FIE that draw on feminist research methods or topics. This workshop is designed to meet the needs of members of the FIE community who have some experience with feminist pedagogies or research methods, and who are looking to develop intellectual relationships with others also working in engineering educational research. We will discuss the history of feminist education and feminist research methods in the US, including a connection to science and engineering education; participants will then work in small groups focusing on a sub-topic (feminist pedagogies, feminist research methods, and feminist research topics/content). We invite participants to bring part of a project (such as a syllabus or course plan, assignment, class or research project, research question or protocol) to this workshop; some time will be dedicated to the guided design/redesign of this project.
\end{abstract}

Index Terms - feminist pedagogies, community of practice, feminist engineering education, feminist research methods

\section{GOALS}

The goal of this session is to provide an opportunity to bring together members of the Frontiers in Education (FIE) community who want to learn more about feminist pedagogies, feminist theory, and feminist research in engineering education during an in-depth and grounded discussion, and to form a community-of-practice to support their development as feminist engineering educators and researchers. Outcomes will be both individual-oriented and group-oriented. Individuals will have an opportunity to redesign a piece of their own work (syllabus or course design, research questions and protocol, or other work) with the guidance of other workshop members and facilitators. In addition, the group as a whole will work together to develop a plan for future sessions and to consider ongoing support of this growing community.

\section{DESCRIPTION OF CONTENT}

FIE has supported a series of special sessions, papers, and workshops on feminist topics since 2004 [1]-[8] with an increasing number of participants attending each year.

However, at the end of each offering, participants tend to express the desire to learn more about how the content is particularly "feminist" and to spend more time doing so; indeed, after the 2008 FIE special session [8], almost onequarter of the 34 people who submitted a feedback form at the end of the session (out of 41 attendees) wanted to have more background and context to the feminist perspective behind the session, while almost $40 \%$ wished for more time to explore the topic in greater depth.

At the same time, there has been growth in the number of research papers incorporating feminist topics or research methods in their construction, both at FIE (ex. [9]-[10]) and in the developing research area situated at the intersection of science and technology studies, women's studies, and engineering studies (ex. [11]-[12]).

This workshop will give participants an opportunity to explore both feminist pedagogies and research methods/topics. Participants will spend 3 hours to learn more deeply the history of feminist theory and thinking in science and engineering educational contexts (including pedagogy, research methods, research topics), and to explore the application of such theory to engineering educational contexts. In addition, participants will have the opportunity to apply what they are learning immediately through working with others on the redesign of a personal project (course syllabus, research questions or methods, assignment, or other document).

The last part of the workshop will be devoted to building a community of practice [13] related to feminist pedagogy in engineering and at FIE. Specifically, the group will explore members' needs for support and goals for future feminist sessions at FIE. We will also use this time also to set up a writing-buddy system amongst volunteers. By the end of this workshop, we hope to have strengthened and formalized this developing community so that it can begin to support members outside of (in addition to inside) the structure of FIE.

\section{WORKSHOP AGENDA}

The following table outlines a proposed agenda for this workshop; timings may adjust depending on participant interest. 
Session S3A

\begin{tabular}{|c|c|}
\hline Time & Activity \\
\hline $10 \mathrm{~min}$ & Introduction to the session and the goals of the session \\
\hline $20 \mathrm{~min}$ & Introductions and goals of participants \\
\hline $20 \mathrm{~min}$ & $\begin{array}{l}\text { Primer on US feminist theory, } 1900 \text {-today. Feminist waves, } \\
\text { mapping feminist science and technology studies over the } \\
\text { top; the tension in labeling pedagogies or research methods } \\
\text { as "feminist" (between resisting compartment-alization and } \\
\text { identifying with history and like-minded people) }\end{array}$ \\
\hline $10 \mathrm{~min}$ & Break \\
\hline \multicolumn{2}{|c|}{15 minutes -- 15 minutes -- 15 minutes } \\
\hline & Rotating simultaneous small group discussions on: \\
\hline & 1. Feminist pedagogies; \\
\hline & Feminist research methods; \\
\hline & 3. Feminist research topics in engineering. \\
\hline & $\begin{array}{l}\text { One of these ideas may be replaced with feminist approaches } \\
\text { to organization and institutional change, depending on } \\
\text { audience interest. This is time to share main ideas, ask } \\
\text { questions, share resources to find out more. }\end{array}$ \\
\hline $30 \mathrm{~min}$ & $\begin{array}{l}\text { Individual design or redesign of brought item (syllabus or } \\
\text { course design, assignment, class or research project, research } \\
\text { question and protocol, or other document) }\end{array}$ \\
\hline $10 \mathrm{~min}$ & Individual reflection and break \\
\hline $35 \mathrm{~min}$ & $\begin{array}{l}\text { Agenda-setting for this group: needs and goals for forming a } \\
\text { community of practice. }\end{array}$ \\
\hline
\end{tabular}

DESCRIPTION OF ANTICIPATED AUDIENCE

The anticipated audience will draw from the core group of participants who have attended the feminist special sessions, workshops and papers for the last 5 years [1]-[8], and a subset of participants who have been attending the philosophy of engineering special sessions and papers from the last 2 years [14]-[15]. However, the audience for this workshop differs from the special session planned on alternative pedagogies at FIE 2009 [16] in that workshop participants should already have some familiarity with feminist or liberative approaches to engineering education, while the special session would assume no prior knowledge.

\section{ACKNOWLEDGEMENT}

We are grateful to the researchers and participants of past FIE sessions focused on feminist topics whose interest has kept a rigorous and invigorating annual discussion growing.

\section{REFERENCES}

Lord, S., Eschenbach, E., Waller, A. A., \& Cashman, E. (2004, October 2023). Interactive Session - Feminist Frontiers. Paper presented at the 34th ASEE/IEEE Frontiers in Education Conference, Savannah, GA.

Lord, S., Cashman, E., Eschenbach, E., \& Waller, A. A. (2005, October 1922). Feminism and Engineering. Paper presented at the 35th ASEE/IEEE Frontiers in Education Conference, Indianapolis, IN.

Eschenbach, E., Cashman, E., Waller, A. A., \& Lord, S. (2005, October 1922). Incorporating Feminist Pedagogy into the Engineering Learning Experience. Paper presented at the 35th ASEE/IEEE Frontiers in Education Conference.

Waller, A. A. (2005, October 19-22). What is feminist pedagogy and how can it be used in CSET education? Paper presented at the 35th ASEE/IEEE Frontiers in Education Conference, Indianapolis, IN.

Waller, A. A. (2005, October 19-22). Work in Progress - Feminist Research Methodologies: Why, What and How. Paper presented at the 35th ASEE/IEEE Frontiers in Education Conference, Indianapolis, IN.
Waller, A. A., Riley, D., Cashman, E., Eschenbach, E., \& Lord, S. (2006, October 28-31). Workshop - Classroom Border Crossings: Incorporating Feminist and Liberative Pedagogies into your CSET classroom. Paper presented at the 36th ASEE/IEEE Frontiers in Education Conference, San Diego, CA.

Riley, D., Catalano, G., Pawley, A., \& Tucker, J. (2007, October 10-13). Special Session: Re-Imaginging Engineering Education: Feminist visions for transforming the field. Paper presented at the 37th ASEE/IEEE Frontiers in Education Conference, Milwaukee, WI.

Tucker, J., Pawley, A., Riley, D., \& Catalano, G. (2008, October 22-25). New Engineering Stories: How Feminist Thinking Can Impact Engineering Ethics and Practice. Paper presented at the 38th ASEE/IEEE Frontiers in Education Conference, Saratoga Springs, NY.

Pawley, A. L. (2007, October 10-13). Gendered boundaries: using a "boundary" metaphor to understand faculty members' descriptions of engineering. Paper presented at the 37th ASEE/IEEE Frontiers in Education Conference, Milwaukee.

Riley, D., Sciarra, G.-L. (2006, October 27-31) "You're all a bunch of fucking feminists:" Addressing the perceived conflict between gender and professional identities using the Montreal Massacre. Paper presented at the $36^{\text {th }}$ ASEE/IEEE Frontiers in Education Conference, San Diego, CA

National Women's Studies Association Science and Technology Taskforce; http://www.nwsa.org/communities/scitech.php

International Network for Engineering Studies, http://www.inesweb.org/.

Wenger, Etienne (1998). Communities of Practice: Learning, Meaning and Identity. Cambridge University Press.

Heywood, J., Harding, T. S., Grimson, W., Korte, R. F., \& McGrann, R. T. R. (2008, October 22-25). Session S4H: Engineering, Engineering Education and Philosophy. Paper presented at the 38th ASEE/IEEE Frontiers in Education Conference, Saratoga Springs, NY.

Heywood, J., McGrann, R. T. R., \& Smith, K. A. (2008, October 22-25). Special Session: Continuing the FIE 2007 Conversation on: Can Philosophy of Engineering Education Improve the Practice of Engineering Education. Paper presented at the 38th ASEE/IEEE Frontiers in Education Conference Saratoga Springs, NY.

Pawley, A, D. Riley, T. Harding, S. Lord, C. Finelli, (2009, October 18-21) Special Session - From Active Learning to Liberative Pedagogies: Alternative teaching philosophies in CSET education. Paper to be presented at the $39^{\text {th }}$ ASEE/IEEE Frontiers in Education Conference, San Antonio, TX.

\section{AUTHOR INFORMATION}

Alice L. Pawley, Assistant Professor, School of Engineering Education, Affiliate with Women's Studies Program, Purdue University, apawley@purdue.edu.

Donna Riley, Associate Professor of Engineering, Smith College,driley@smith.edu.

Susan M. Lord, Professor of Electrical Engineering, University of San Diego, slord@sandiego.edu.

Trevor Harding, Associate Professor, Materials Engineering, California Polytechnic State University, tharding@calpoly.edu 